Saudi Journal of Business and Management Studies Abbreviated Key Title: Saudi J Bus Manag Stud ISSN 2415-6663 (Print) |ISSN 2415-6671 (Online) Scholars Middle East Publishers, Dubai, United Arab Emirates Journal homepage: https://saudijournals.com

Original Research Article

\title{
The Effect of Technology and Competition on Business Development
}

\author{
${ }^{1}$ Universitas Pakuan, Bogor, Indonesia \\ ${ }^{2,3}$ Universitas Harapan, Medan, Indonesia \\ ${ }^{4}$ STIM Sukma, Medan, Indonesia
}

Prasetyono Hendriarto ${ }^{1 *}$, Bunga Aditi $^{2}$, Hafizah $^{3}$, Riandani Rezki Prana ${ }^{4}$

DOI: $10.36348 / \mathrm{sjbms.2021.v06i03.005}$

| Received: 02.03.2021 | Accepted: 20.03.2021 | Published: 25.03.2021

*Corresponding author: Prasetyono Hendriarto

\section{Abstract}

The research analysis aims to determine whether technology and competition have an effect on the business development of SMEs in the Center for Integrated Business Services of the Cooperative for Micro, Small, and Medium Enterprises, North Sumatra. The data analysis technique used is the associative method with the help of the SPSS version 24.0 program. The population in this study were all UKM players who traded in the Center for Integrated Business Services of Cooperatives, Micro, Small and Medium Enterprises, North Sumatra, and a sample of 60 respondents. Primary data collection using a questionnaire. The results showed that technology partially had a positive and significant effect on the business development of SMEs in the Center for Integrated Business Services of Cooperatives for Micro, Small, and Medium Enterprises, North Sumatra. Partial competition does not have a positive and insignificant effect on the business development of SMEs in the Integrated Business Service Center for Cooperatives, Micro, Small, and Medium Enterprises, North Sumatra. Technology and competition simultaneously have a positive and significant effect on the business development of SMEs in the Integrated Business Service Center for Micro, Small, and Medium Enterprises, North Sumatra Cooperatives.

Keywords: Technology, Competition, Business Development.

Copyright (0) 2021 The Author(s): This is an open-access article distributed under the terms of the Creative Commons Attribution 4.0 International License (CC BY-NC 4.0) which permits unrestricted use, distribution, and reproduction in any medium for non-commercial use provided the original author and source are credited.

\section{INTRODUCTION}

Basically, the goal of every small and medium business actor is to maintain the viability of his business. In other words, small and medium business actors try to achieve a profitable sales volume level because it can measure the company's position with calculated profits to be obtained. In promoting their products to consumers, small and medium enterprises use technology as a tool to introduce the products they will market.

Technological progress is one of the considerations of society in meeting their needs. With the rapid development of technology, people call it the HiTech or NewTech era, the convenience, and quality offered by technological advances are a plus in the eyes of the community. Now technology has become a general need and is very important so that it affects the business world, which is very dependent on the developing scheme of people's lives. Technology is useful for marketing/promoting products to be sold to consumers. Technology also makes it easier for small and medium businesses to respond to complaints, criticisms, or suggestions given by consumers in order to improve and develop products to be sold.

Another factor that needs to be considered in relation to the constraints of micro, small and medium enterprises is competition. Weak access to market information and not optimal products of micro, small and medium enterprises in reaching consumers could be caused by weak or sub-optimal small and medium entrepreneurs making product innovations to survive the business competition. The business competition involves other business units in business activities carried out by producers, both in production and product marketing activities. Producers use intermediaries because they create greater efficiency in providing goods to the target market. Through contacts, experience, specialization, and scale of operations, 
Prasetyono Hendriarto et al., Saudi J Bus Manag Stud, Mar, 2021; 6(3): 86-90

intermediaries usually offer companies more than what small and medium enterprises can achieve. Business competition is also a social process when there are two or more parties competing with each other and doing something to achieve certain victories. This competition can occur when there are several parties who want something that is limited in number or becomes the center of public attention. Because business actors can specialize so that business is more efficient, reduces transaction costs, and increases flexibility due to the presence of trusted partners.

According to Beik [4] factors that influence business development consist of internal and external factors, namely: (1) ability to produce quality goods, (2) total sales, (3) price, (4) venture capital, (5) design, (6) competitiveness, (7) ability to choose the type of business. Meanwhile, external factors that are thought to influence are (1) imported faucets that must be limited, (2) raw material prices, (3) transportation costs, (4) number of buyers, (5) production costs, (6) equipment technology, (7) marketing area and product diversification. Furthermore, research from Apriwiyanti [1] found that technology has a significant effect on business development. Lestari, Lubis, and Widayanto [3] found that competition has a significant effect on business development.

In addition, current business development requires business actors to be more responsive to any changes that exist in today's business world. In running their business, small and medium enterprises are not only required to improve the welfare of owners and employees but also be able to accommodate other interested parties. In addition, companies must also be able to meet the increasingly complex demands of society for their needs. Especially with the economic conditions in Medan City that continue to be hit by shocks, forcing small and medium enterprises to be able to adapt to these conditions by increasing the added value of the company.

The North Sumatra Cooperative Micro, Small and Medium Enterprise Integrated Business Service Center is one of the business sectors that continues to experience growth. As population growth in Medan City increases, the volume of demand for an integrated business service center for the North Sumatra Micro, Small, and Medium Enterprises Cooperative continues to increase. The tendency of the people of Medan to enjoy Ready eat food and Fashionable T-shirts or dresses has led to the emergence of many new businesses in the fields of food and beverage and clothing. Therefore, competition between companies is getting stronger. With this increasingly strong competition, it requires small and medium business actors to strengthen their fundamentals so that small and medium enterprises can compete with other similar small and medium business actors. Meanwhile, one of the main objectives of the North Sumatra Micro, Small and Medium Enterprise Cooperative, integrated business service center is to maximize business value or increase the level of prosperity of stakeholders. The health level of small and medium business actors is important for small and medium business actors to increase efficiency in running their business so that the ability to earn profits can be increased and to avoid potential bankruptcy.

\section{RESEARCH METHODOLOGY}

The type of research method used is quantitative research methods with an associative approach. This research was conducted at the Center for Integrated Business Services for Cooperatives of Micro, Small and Medium Enterprises, North Sumatra, which is located at Jenderal Gatot Subroto Street, KM. 5, Sei Sikambing C. II, Medan Helvetia, Medan City, and North Sumatra, Indonesia. In this study, the population is all small and medium business actors, amounting to 60 SMEs trading in the Center for Integrated Business Services, Cooperatives, Micro, Small and Medium Enterprises, North Sumatra. Because the population is too small, the sample determination uses the saturated sampling method, namely the sampling technique when all members of the population are used as the sample.

The indicator used to measure technological variables uses 7 measurement indicators following the opinion of Ali and Wangdra [2]. Furthermore, there are 5 indicators for competition following the opinion of Santoso [5]. And the indicators of business development are 3 indicators following the opinion of Putri et al. [4].

The data collection technique used a questionnaire with a Likert scale of 1-5. The analysis tool used in SPSS 24.0. Data analysis techniques used data quality tests (validity and reliability tests), classical assumption tests (normality test, heteroscedasticity test, and multicollinearity test), conformity test (multiple linear regression test, t-test, and F test), and determination coefficient tests.

\section{RESEARCH RESULTS AND DISCUSSION a. Characteristics of Respondents}

The majority of business traders in the Integrated Business Service Center who became respondents were male and female, namely 31 people or $51.7 \%$ of the men and 29 women or $48.3 \%$ of the total respondents. Respondents aged 21-30 years, as many as 25 people or $41.7 \%$ of the total respondents, this shows that business actors in the integrated business service center of the Cooperative, Micro, Small and Medium Enterprises, North Sumatra, are the majority of the millennial generation, with an income of Rp. 5,000,000 - Rp. $10,000,000$, which is 21 people or $35.0 \%$ of the total respondents, this shows that the SME actors in PLUT Cooperative, Micro, Small and Medium Enterprises, North Sumatra have better income. 
Prasetyono Hendriarto et al., Saudi J Bus Manag Stud, Mar, 2021; 6(3): 86-90

Furthermore, it is known that the number of workers owned is not there, namely as many as 20 people or $33.3 \%$ of the total respondents, this shows that business actors in the Integrated Business Service Center of the Cooperative, Micro, Small and Medium Enterprises, North Sumatra do not have workers, they prepare everything themselves. Ownership status of business premises owned by their own businesses was 24 people or $40.0 \%$ of the total respondents.

Based on the origin of the initial information opening a business from a family, as many as 15 people or $25.0 \%$ of the total respondents, this shows that business actors in the North Sumatra Micro, Small and Medium Enterprise Cooperative, Integrated Business Service Center opened a business there based on information from the family Duration of trading at the Integrated Business Service Center for Micro, Small and Medium Enterprises Cooperatives in North Sumatra for 2 - 3 years, namely as many as 34 people or $56.7 \%$. The products sold at the North Sumatra Micro, Small and Medium Enterprises Cooperative, Ulos integrated business service center, which are as many as 15 people or $25.0 \%$ of the total respondents, shows that business actors in the Integrated Business Service Center for the Micro, Small and Medium Enterprises Cooperative of North Sumatra are the majority of sellers. Ulos.

\section{b. Data Quality Test}

The results of the SPSS output show that the validity value contained in the Corrected item-total Correlation column is greater than 0.30 . So it can be concluded that every statement in the research is said to be valid or valid. The results of the SPSS output show that the Cronbach Alpha value of all the research variables, namely: the technology variable, the Cronbach Alpha value is 0.615 , the Cronbach alpha value is 0.897 , and the Cronbach Alpha value for business development is 0.733 , where all the variables in the study are Cronbach Alpha value> 0.60 So it can be concluded that the questions presented to respondents are reliable or reliable.

\section{c. Classic Assumption Test \\ 1) Normality Test}

The results of the data normality test using PP Plot images show the scattered data points are around the diagonal line so that the data has been distributed normally. Here's a graphic image:

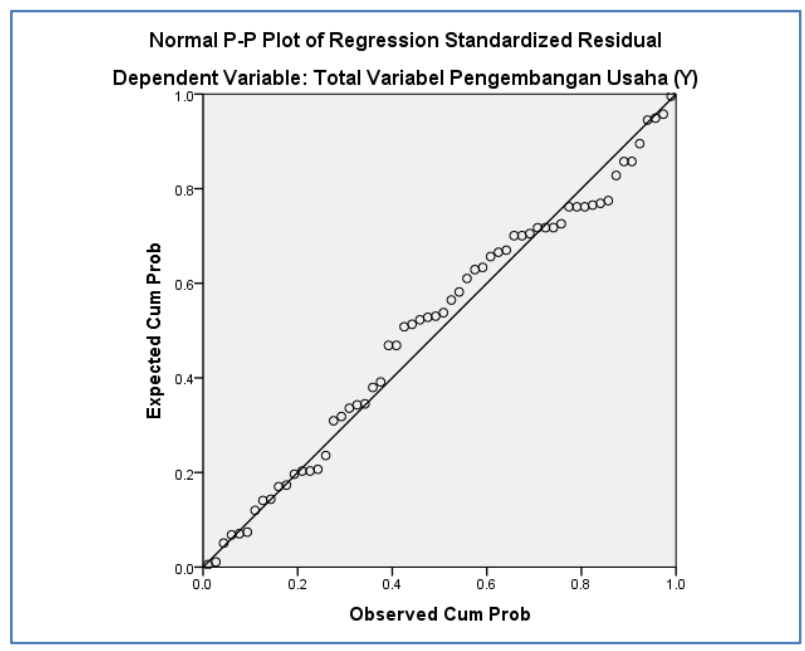

Fig 1: PP-Plot Grafik

Furthermore, by using the Kolmogorov Smirnov test, it can also be seen that the data is normally distributed with a significance value greater than $0.05(\mathrm{p}=0.200<0.05)$.

Table-1: Kolmogorov-Smirnov Test

\begin{tabular}{|c|c|c|}
\hline & & Unstandardized Residual \\
\hline \multicolumn{2}{|c|}{$\mathrm{N}$} & 60 \\
\hline \multirow{2}{*}{ Normal Parameters ${ }^{\mathrm{a}, \mathrm{b}}$} & Mean & .0000000 \\
\hline & Std. Deviation & 2.31052116 \\
\hline \multirow{3}{*}{$\begin{array}{l}\text { Most Extreme } \\
\text { Differences }\end{array}$} & Absolute & .092 \\
\hline & Positive & .088 \\
\hline & Negative & -.092 \\
\hline \multicolumn{2}{|c|}{ Test Statistic } & .092 \\
\hline \multicolumn{2}{|c|}{ Asymp. Sig. (2-tailed) } & $.200^{\mathrm{c}, \mathrm{d}}$ \\
\hline \multicolumn{3}{|l|}{ a. Test distribution is Normal. } \\
\hline \multicolumn{3}{|l|}{ b. Calculated from data. } \\
\hline \multicolumn{3}{|c|}{ c. Lilliefors Significance Correction. } \\
\hline \multicolumn{3}{|c|}{ d. This is a lower bound of the true significance. } \\
\hline
\end{tabular}

\section{2) Heteroscedasticity Test}

In this study, the method used to detect heteroscedasticity symptoms was by looking at the scatterplot graph between the predictive value of the dependent variable (ZPRED) and its residual (SRESID). Here's the picture: 
Prasetyono Hendriarto et al., Saudi J Bus Manag Stud, Mar, 2021; 6(3): 86-90

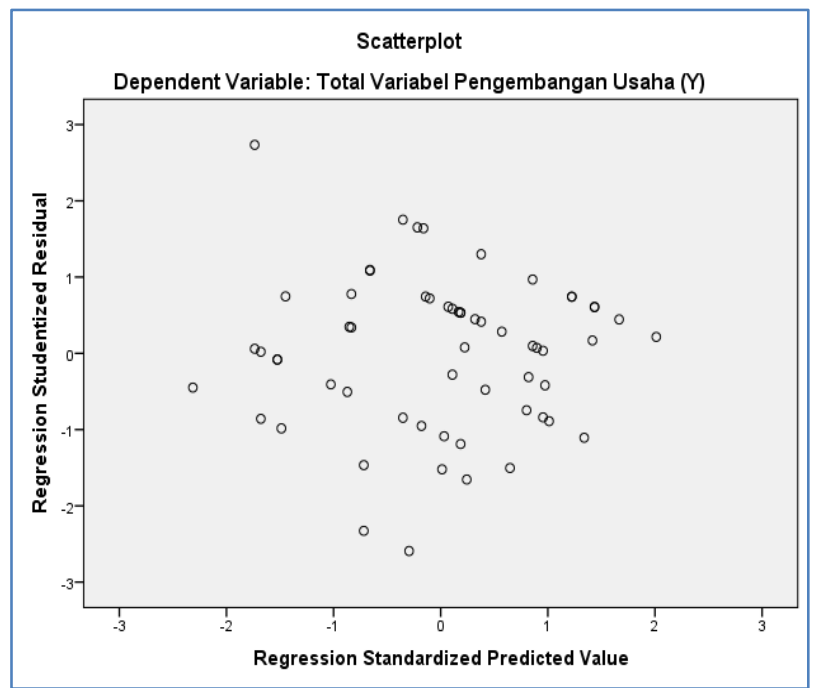

Fig-2: Scatterplot Graph

The scatterplot image shows that the dots are randomly distributed and do not form a particular pattern or trend line. The results of this test indicate that this regression model is free from heteroscedasticity problems.

\section{3) Multicollinearity Test}

It can be seen that technology and competition have a Tolerance value $>0.1$ and a VIF value $>10$, so it can be concluded that there is no multicollinearity symptom (between independent variables has no correlation). For more details, it can be seen from the following table:

Table-2: Multicollinearity Test

\begin{tabular}{|c|c|c|c|}
\hline \multicolumn{4}{|c|}{ Coefficients $^{\mathrm{a}}$} \\
\hline \multirow{2}{*}{\multicolumn{2}{|c|}{ Model }} & \multicolumn{2}{|c|}{ Collinearity Statistics } \\
\hline & & Tolerance & VIF \\
\hline \multirow[t]{2}{*}{1} & Technology & .995 & 1.005 \\
\hline & Competition & .995 & 1.005 \\
\hline
\end{tabular}

\section{d. Data Analysis Test}

1) Multiple Linear Regression Test

Multiple linear regression aims to calculate the influence of two or more independent variables on one dependent variable and predict the dependent variable using two or more independent variables. Based on the analysis, the multiple linear regression equation is obtained as follows:

$\mathrm{Y}=10.474+0.319 \mathrm{X} 1-0.058 \mathrm{X} 2$

\section{2) Hypothesis Test}

\section{a. Partial Test (t-Test)}

A partial test is conducted to determine the influence of the independent variable on the dependent variable. The t-test results are attached below.

Table-2: $t$ Test

\begin{tabular}{|c|c|c|c|c|c|c|}
\hline \multicolumn{7}{|c|}{ Coefficients $^{\text {a }}$} \\
\hline & \multirow[t]{2}{*}{ Model } & \multicolumn{2}{|c|}{$\begin{array}{l}\text { Unstandardized } \\
\text { Coefficients }\end{array}$} & \multirow{2}{*}{$\begin{array}{c}\begin{array}{c}\text { Standardized } \\
\text { Coefficients }\end{array} \\
\text { Beta } \\
\end{array}$} & \multirow[t]{2}{*}{$\mathrm{t}$} & \multirow[t]{2}{*}{ Sig. } \\
\hline & & B & Std. Error & & & \\
\hline \multirow[t]{3}{*}{1} & (Constant) & 10.474 & 3.157 & & 3.318 & .002 \\
\hline & Technology & .319 & .066 & .537 & 4.832 & .000 \\
\hline & Competition & -.058 & .045 & -.145 & -1.301 & .198 \\
\hline
\end{tabular}

Based on the table above, it can be seen that Tcount in technology is 4,832 while T-table is 2,002 and T-table is $-1,301$ while T-table is 2,002 which can be seen at $\alpha=0.05$ (see attachment table $\mathrm{T}$ ). The probability of significance is much smaller than 0.05 , namely $0.000<0.05$, the regression model can be said that in this study, technology has a positive and partially significant effect on business development, while competition has no positive and partially insignificant effect on business development. The hypothesis is Ha (accepted) and H0 (rejected).

\section{b. Simultaneous Test (F-Test)}

A partial test is conducted to determine the influence of the independent variable on the dependent variable. The variables here are entrepreneurial knowledge (X1), entrepreneurial personality (X2), and external factors (X3).

Table-3: F Test

\begin{tabular}{|c|c|c|c|c|c|c|}
\hline \multicolumn{7}{|c|}{ ANOVA $^{\text {a }}$} \\
\hline \multirow{2}{*}{1} & Model & Sum of Squares & Df & Mean Square & F & Sig. \\
\cline { 2 - 7 } & Regression & 134.011 & 2 & 67.006 & 12.126 & $.000^{\mathrm{b}}$ \\
\cline { 2 - 7 } & Residual & 314.972 & 57 & 5.526 & & \\
\cline { 2 - 7 } & Total & 448.983 & 59 & & & \\
\hline
\end{tabular}


Prasetyono Hendriarto et al., Saudi J Bus Manag Stud, Mar, 2021; 6(3): 86-90

It can be seen from the simultaneous test results in the table above that it can be seen that F-count is 12,126 while Ftable is 3.15 which can be seen at $\alpha=$ 0.05 (see attachment $\mathrm{F}$ table). The significant probability is much smaller than 0.05 , namely 0.000 $<0.05$, so the regression model can be said that in this study technology and competition simultaneously have a significant effect on business development. Then the previous hypothesis is Accept Ha or the hypothesis is accepted.

\section{b. Coefficient of Determination}

Here are the results of the determination test:

Table-4: Coefficient of Determination

\begin{tabular}{|c|c|c|c|c|}
\hline \multicolumn{5}{|c|}{ Model Summary } \\
\hline Model & $\mathrm{R}$ & R Square & Adjusted R Square & Std. Error of the Estimate \\
\hline 1 & $.546^{\mathrm{a}}$ & .298 & .274 & 2.351 \\
\hline
\end{tabular}

It can be seen that the Adjusted R Square value of 0.274 or $27.4 \%$ means that the independent variables of technology and competition are able to explain variations of the dependent variable on business development by $27.4 \%$ while the remaining $100 \%$ $27.4 \%=72.6 \%$ is influenced by other variables that are not researched or not included. in the research model.

\section{CONCLUTION}

a) Technology partially has a positive and significant effect on the Business Development of SMEs in the Integrated Business Service Center for Cooperatives, Micro, Small and Medium Enterprises, North Sumatra.

b) Partial competition does not have a positive and insignificant effect on the Business Development of SMEs in the Integrated Business Service Center for Cooperatives, Micro, Small and Medium Enterprises, North Sumatra.

c) Technology and competition simultaneously have a positive and significant effect on the Business Development of SMEs in the Integrated Business Service Center for the Cooperative, Micro, Small, and Medium Enterprises, North Sumatra.

\section{REFERENCES}

1. Apriwiyanti, I. (2019). Pengaruh pinjaman modal dan teknologi terhadap perkembangan umkm menurut perspektif ekonomi islam di kota bandar lampung (Studi Kasus Sentra Industri Keripik Pisang Jalan Pagar Alam, Segala Mider (Doctoral dissertation, UIN Raden Intan Lampung).

2. Hapzi, A.D., Tonny, W. (2010). Technopreneurship dalam Perspektif Bisnis Online. Jambi: Baduose Media.

3. Lestari, C., Lubis, N., \& Widayanto, W. (2015). Pengaruh Jaringan USAha, Inovasi Produk Dan Persaingan USAha Terhadap Perkembangan USAha Mikro, Kecil Dan Menengah (Studi Pada IKM Makanan Di Kecamatan Kuningan Kabupaten Kuningan Jawa Barat). Jurnal Ilmu Administrasi Bisnis, 4(2), 185-196.

4. Putri, K., Pradhanawati, A., \& Prabawani, B. (2014). Pengaruh karakteristik kewirausahaan, modal usaha dan peran business development service terhadap pengembangan usaha (studi pada sentra industri kerupuk desa kedungrejo sidoarjo jawa timur). Jurnal Ilmu Administrasi Bisnis, 3(4), 313-322.

5. Santoso, E. B. (2009, October). Daya saing kotakota besar di Indonesia. In Seminar Nasional Perencanaan Wilayah dan Kota ITS, Surabaya (Vol. 29). 